Indians on their plantations." Yet this people possesses a perfect set of the primitive ideas and practices illustrated in "The Golden Bough." Totemism, tabu, initiation, exogamy, reincarnation, the couvade, new fire, and the medical practice and food regulations found among the rude Australians-these and other primitive ways flourish here. They are not " survivals," but living realities, forming the warp of the social fabric.

This meeting of old and new may be partially realised by the illustration, here reproduced, of the " new fire" ceremony, which forms part of the New Year festival.

The Yuchis constitute an independent linguistic stock. A hundred years after their incorporation with the Creek Confederacy they left Georgia for the west of the Mississippi, in 1836 . They now number about 500 , in three "towns," and are "a remarkably strong and healthy set of people."

The clan-system is in use, based on maternal descent and totemism. The members are relatives and descendants of certain pre-existing animals, the oiaron of other American tribes. The Bear clan worships and protects the bear, getting bear's meat from the

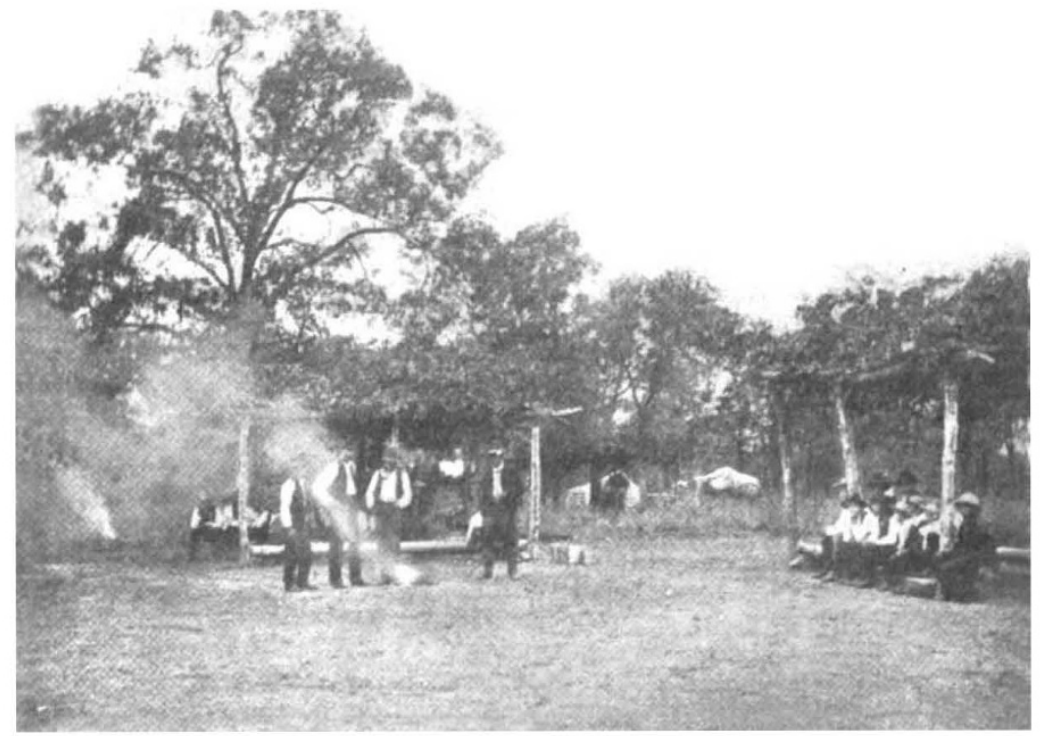

New Fire Rite. Second Day, Annual Ceremony.

Deer clan, and so on. Above the clan-system is the Society or Class. The entire male population is divided into the Chief Society and the Warrior Society. Above this is the Town or Tribe.

Mr. Speck's careful inquiry brings out several interesting points. Students of ballistics will be glad to know that the principle of "rifling" was used in barbarous ages. It is applied to the feathers of arrows. They are twisted so as to make the arrow revolve in its flight.

An important phase of animistic theory is connected with birth. Until the fourth day the child has not "severed all the bonds which link it with the supernatural." On that day it is fed for the first time, and receives a name. "It is then no longer a halfspirit, but a real human being, and belongs to earth.", (My italics.)

The origin of the tribe is traced to the Sun, and at the New Year festival the town-square is represented as a rainbow. This festival is a good example of primitive ritual, comprising fasting, various tabus, scarification, the rite of the emetic, totemistic drama, inoculation against evil during the coming year, the kindling of sacred fire, and the ceremonial eating of the new corn.

Mr. Speck's interests are chiefly linguistic, but he has made a valuable contribution to general ethnology. The Pennsylvania Lniversity Museum is to be congratulated on its first anthropological publication.

\section{MALARIA AND ITS INFLUENCE ON NATIONAL HISTORY.}

WIDESPREAD disease, in the form of plagues and pestilences, has profoundly influenced the course of events, local or national, in various countries. The Biblical narrative contains instances of this, and the black death left its mark on European history; in fact, Dr. Gasquet regards the black death as the most important event of the Middle Ages, and a prime factor in the making of modern England. The presence of disease in a locality may in many ways disturb life and enterprise there. Thus the failure of the early attempts to cut the Panama Canal may in part be attributed to the terrible mortality among the labourers, principally from malignant malarial fevers, and the existence of tsetse-fly disease (which attacks horses, \&c.) in wide tracts of country in Africa has rendered the problem of transport and the opening up of such districts a difficult one. Prescott, in his "History of the Conquest of Mexico," though writing without the knowledge we now possess, remarks that we find no mention in the records of any uncommon mortality among the conquerors, Cortes and his companions. Had yellow fever and malaria prevailed in the country as they have done in more recent times, in all probability the Spanish conquest of Mexico would never have been accomplished.

Similarly, the introduction of diseases into districts previously free from them may so disturb the balance that the subsequent history of such districts may be entirely altered. A modern instance of this is the introduction of malaria into Mauritius. Until fifty years ago or thereabouts this disease was unknown in these islands; it was then introduced, probably from India, and has since caused serious loss through sickness, in life and by depreciation in the value of property.

It is but a step from a consideration of specific local instances such as these to the suggestion that the introduction of diseases which have the capacity of spreading widely may modify the characteristics and subsequent history of whole nations. This theme in the case of Greece and Rome has been elaborated by Mr. W. H. S. Jones, who sees in the introduction of malaria into these empires at least one of the important factors which helped their decline and fall.

In his "Malaria and Greek History," 1 Mr. Jones corrects and develops the theory put forward in a previous work (see Nature, March I9, Igo8, vol. Ixxvii., p. 457), that man, in the struggle for existence, has to compete, among other enemies, with disease-producing parasites, that even if he is not exterminated by

1 "Malaria and Greek Hittory." By W. H. S. Jones. To which is added "The History of Greek Therapeuics and the Malaria Theory." By E. T. Withington. Pp. x+r75. (Manchester: University Press, 1909.) Price $5 s$. net.

NO. 2094, VOL. 82] 
the disease-parasite, this may so weaken him that he falls an easy victim to his healthier neighbours.

Mr. Jones believes that malaria played a considerable part in bringing about the decline of the ancient Greeks, that this disease fell like a blight upon many fertile districts of Greece, as it almost certainly did upon Attica in the fifth century B.c.

$\mathrm{He}$ considers it is at least doubtful if Greece were malarious in early times. For the truth of the theory, it is not, however, necessary to prove (which is impossible) that malaria did not exist in early Greece. For, as Prof. Ronald Ross has pointed out in a recent paper, 1 even if the anopheline mosquitoes, which convey the disease, are present, provided the number of infected persons are few, the spread of infection would be slight or stationary, and the disease might fail for centuries to make headway. If, however, a number of infected immigrants make their appearance, endemic cases will increase, first slowly, then rapidly, until suddenly a widespread epidemic will occur.

In the first chapter of the book the prevalence of malaria in modern Greece and its effect on the inhabitants are discussed. In the two following chapters the evidence contained in the ancient medical and non-medical writers of the existence of malaria in ancient Greece is critically examined. The author believes that on the whole it is safe to conclude that malaria was not prevalent to any extent in early Greece; there are but two doubtful references to the disease before 500 B.C. As regards Attica, there is evidence to show that from the end of the fifth century B.C. malaria began to be prevalent. The disease is referred to in the plays of Aristophanes, and the Decelean and Peloponnesian wars gave opportunity for its spread, partly by the immigration of infected individuals, partly by the neglect of cultivation and drainage of the land, and the increase of the breeding places of the mosquitoes induced thereby.

The history of Greek medicine after 400 B.c. shows a decline in the scientific treatment of disease, and a growing popularity of the dream oracle, charms, and other superstitions, which has never been adequately explained; but it is suggested that the prevalence of malaria, which cannot be treated without quinine, might explain the growth of such superstitious practices. This theme is the subject of an interesting essay by Dr. E. T. Withington.

The condition of the Greeks before the final triumph of Rome seems to have been lamentable-they displayed want of good faith and lack of courage, they had lost ambition and cared for little but pleasure, and brutality, cruelty and vice of all kinds were rife. This period coincides, according to the evidence collected by Mr. Jones, with that during which malaria spread and became prevalent, and he believes that this decadence of the Greek character may in part at least be ascribed to the ravages of this disease. An amount of evidence is accumulated to show that in a malaria-stricken country the inhabitants lose their vigour and moral sense, and become degraded physically and mentally.

Turning now to the case of Rome, Mr. Jones, in an interesting essay, ${ }^{2}$ from which we shall quote, similarly seeks to show that malaria exercised a powerful (though to a great extent uncertain) influence upon Roman history and Roman life.

Cicero (first century в.c.) records that on the Palam tine hill there was a shrine and altar dedicated to the goddess Fever. This altar, we may remark, is also mentioned by Epictetus (Dissertations), and Pliny

1 Report on the Prevalence of Malaria in Mauritius.

2 "Dea Febris: a Study of Malaria in Ancient Italy." By W. H. S, Jones. Issued by the Liverpool School of Axchæology. Pp. 28. (Liverpool: University Press, xgog.) Price $1 .$.

NO. 2094, VOL. 82] says that it had State recognition (both first century A.D.). Although febris may be used to denote any febrile condition, it usually means malaria, and the deification of fever is clear proof that it played no small part in the lives of the Romans. As in the case of Greece, the problem arises, has Italy always suffered from the plague of malaria? Many writers have pointed out that some districts (e.g. parts of Etruria and Latium), which are now scarcely habitable, were at one time the homes of great and prosperous peoples.

In the very early period, Rome was marshy, but the land around it well drained, cultivated, and the home of prosperous communities, and there is no reason to suppose that malaria was present. By 500 B.c. malaria was in the peninsula, Sybaris being undoubtedly infected, and by the end of the Republic, Sardinia, Sicily, Etruria, Apulia, Latium, the southern coast-line, and Rome itself were all malarious. While not to be regarded as one of the causes of the downfall of the Roman Empire, malaria, Mr. Jones considers, greatly influenced the course of events, and was a serious factor in the lives of the Romans.

Mr. Jones has developed his arguments in a decidedly convincing manner with a wealth of references to classical and modern authorities, and if he has not completely proved his case, the contents of his book and essay are very suggestive, as well as being most interesting reading.

A word in conclusion. Is it not possible that malaria has also played a part in this England of ours? There is a consensus of opinion that parts of Norfolk were once much more populated than is the case at present, as witness the numbers of large and beautiful churches that still exist. Again, within a radius of about three miles round Newchurch, in Romney Marsh, Kent, there are some ten old churches and ruins of two or three others, many more than are now required for the needs of the district, which is sparsely populated and the same obtains more or less for the whole of the Marsh, where anopheline mosquitoes are still abundantly present, as the writer has found. Both Norfolk and Romney Marsh were formerly very malarious. Has malaria been one of the factors causing the depopulation of these localities?

\section{R. T. Hewlett.}

\section{STATE AID FOR AGRICULTURAL EDUCATION.'}

THE annual report on the distribution of grants for agricultural education and research in $1907-8$, lately issued, is a notable volume by reason of the excellent discussion of the whole subject by Prof. Middleton, one of the secretaries of the Board. The total amount expended for education was 12, rool., an increase of $550 l$. over the preceding year; the total number of students attending the various institutions was 1313 , an increase of 92 . The numbers are far from satisfactory in view of the fact that some ro,ooo young men probably take up farming each year, whilst a certain proportion of the agricultural students do not go in for it at all, at any rate in England. Why does not the farmer take greater advantage of the opportunities for educating his sons? It is hardly a question of means, for agricultural education is very cheap and scholarships are liberally given; nor is it that the farmers do not know of the existence of the colleges. The real reason, probably, is that the farmer is not satisfied as to the value of agricultural education. Prof. Middleton has drawn up a table

1 Board of Agriculture and Fisheries. Annual Report on the Distribution of Grants for Agricultural Education and Research in the Year rgo7-8. [Cd. 4802.] (rgog.) Price rod. 